\title{
PENERAPAN METODE PEMBELAJARAN GROUP TO GROUP (GGE) UNTUK MENINGKATKAN HASIL BELAJAR SISWA
}

\author{
D. P. Yuliana Eka Shaputra1 ${ }^{1}$, N. Santiyadnya ${ }^{2}$, A. Adiarta ${ }^{3}$ \\ 1,2,3Prodi Pendidikan Teknik Elektro,Universitas Pendidikan Ganesha, Singaraja \\ e-mail: dewashaputracoc@gmail.com, santiyadnya@yahoo.com, adiarta_pohgending@yahoo.com
}

\begin{abstract}
Abstrak
Penelitian ini bertujuan untuk mengetahui adanya peningkatan hasil belajar siswa dalam mata pelajaran Prakarya dan Kewirausahaan dengan penerapan metode pembelajaran Group to Group Exchange (GGE) di kelas X MIPA 2 SMA Negeri 4 Singaraja Tahun Ajaran 2016-2017. Jenis penelitian ini adalah PTK (Penelitian Tindakan Kelas) yang dilaksanakan dalam 2 Siklus. Subjek penelitian ini adalah siswa kelas X MIPA 2 SMA Negeri 4 Singaraja yang berjumlah 39 orang dan terdiri dari 20 orang laki-laki dan 19 orang perempuan. Siklus I terdiri dari 3 kali pertemuan dan Siklus II terdiri dari 3 kali pertemuan, dengan menggunakan metode pengumpulan data berupa metode observasi dan tes. Data yang diperoleh adalah berupa peningkatan hasil belajar siswa yang mencakup ranah kognitif, afektif dan psikomotor. Data hasil belajar yang terkumpul dianalisis secara deskriptif kuantitatif. Hasil penelitian ini menunjukkan bahwa penerapan metode pembelajaran Group to Group Exchange (GGE) di kelas X MIPA 2 SMA Negeri 4 Singaraja dapat meningkatkan hasil belajar Prakarya dan Kewirausahaan. Hal ini dapat dilihat dari peningkatan hasil belajar Prakarya dan Kewirausahaan dari Siklus I sampai Siklus II. Rata-rata hasil belajar siswa pada Siklus I mencapai 71 dan 78,27 pada Siklus II, terjadi peningkatan sebesar 7,27. Ketuntasan belajar klasikal juga meningkat dari $58 \%$ pada Siklus I menjadi $87 \%$ pada Siklus II, terjadi peningkatan sebesar $29 \%$.
\end{abstract}

Kata kunci: metode GGE, hasil belajar, prakarya dan kewirausahaan

\begin{abstract}
This study aimed at knowing the improvement of students' achievement in "Prakarya and Kewirausahaan" subject matters by using method Group to Group Exchange (GGE) at X MIPA 2 of SMA Negeri 4 Singaraja in academic year of 2016-2017. This study was classroom action research which was conducted in 2 cycles. The subject of this study was students of X MIPA 4 of SMA Negeri 4 Singaraja with the number of students was 39 students consisted of 20 male students and 19 female students. Cycle 1 consisted of 3 meetings and cycle 2 consisted of 3 meetings, the data was collected by using observation and test. The data was obtained in the form of students' achievement which is covered cognitive aspect, affective, and psychomotor. The data was analyzed through descriptive quantitative. The result of this study showed that the implementation of method Group to Group Exchange (GGE) at X MIPA 2 of SMA Negeri 4 Singaraja could improve the result of students' achievement in "Prakarya and Kewirausahaan" subject matters. The mean score of students achievement in the cycle 1 was 71 and for cycle 2 was 78.27. From the result in the cycle 1 and 2, the improvement of students achievement was Classical mastery learning also improved for the cycle 1 was $58 \%$ became $87 \%$ in the cycle 2, the improvement of students achievement was $29 \%$.
\end{abstract}

Keywords: Method GGE, students' achievement, A craft and entrepreneurship 


\section{Pendahuluan}

Pendidikan merupakan proses perubahan sikap dan tingkah laku seseorang atau sekelompok orang dalam usaha mendewasakan manusia melalui upaya pengajaran dan latihan. Menurut Prof. Brodjonegoro (dalam Purwanto, 2014:20) pendidikan adalah suatu tuntunan kepada pertumbuhan manusia mulai lahir sampai tercapainya kedewasaan secara jasmani dan rohani agar dapat memenuhi sendiri tugas hidupnya. Kegiatan pendidikan merupakan usaha yang dilakukan secara sengaja, penuh kesadaran, dan tanggung jawab. Pendidikan merupakan suatu kebutuhan yang harus dipenuhi dalam kehidupan bermasyarakat, berbangsa, dan bernegara. Peranan pendidikan sangatlah penting, sebab pendidikan merupakan lembaga yang berusaha membangun masyarakat dan watak bangsa secara berkesinambungan. Menurut pendapat Ki Hadjar Dewantoro (dalam Purwanto, 2014:23) di jelaskan bahwa pendidikan sebagai daya upaya untuk memajukan perkembangan budi pekerti sebagai daya upaya untuk memajukan perkembangan budi pekerti (kekuatan batin), pikiran (intelek) dan jasmani anak - anak. Sehingga pendidikan merupakan salah satu bagian yang sangat penting dalam pembangunan nasional dengan mengupayakan perluasan dan pemerataan kesempatan dalam memperoleh pendidikan yang bermutu tinggi bagi seluruh rakyat Indonesia menuju terciptanya manusia Indonesia yang berkualitas.

Di dalam UU RI No. 20 di paparkan bahwa pendidikan merupakan usaha sadar dan terncana untuk mewujudkan suasana belajar dan proses pembelajaran agar peserta didik secara aktif mengembangkan potensi dirinya untuk memiliki kekuatan spiritual keagamaan, pengendalian diri, kepribadian, kecerdasan, akhlak mulia, serta keterampilan yang di perlukan dirinya, masyarakat, bangsa, dan negara. Atau dengan kata lain pendidikan merupakan sumber dari perkembangan manusia di segala aspek kehidupan yang sangat penting untuk dikembangkan.

Pembelajaran merupakan proses interaksi peserta didik dengan guru, untuk membantu peserta didik agar dapat belajar dengan baik. Menurut Undang - Undang Sistem Pendidikan Nasional No. 20 Tahun 2003 menyatakan pembelajaran adalah "proses interaksi peserta didik dengan pendidik dan sumber belajar pada suatu lingkungan belajar". Pembelajaran sebagai proses belajar yang di bangun oleh guru untuk mengembangkan kreatifitas berfikir yang dapat meningkatkan kemampuan mengkontruksikan pengetahuan baru sebagai upaya meningkatkan penguasaan yang baik terhadap materi pembelajaran. Pembelajaran yang bermakna akan membawa siswa pada pengalaman belajar yang mengesankan. Pengalaman yang diperoleh siswa akan semakin berkesan apabila dalam proses pembelajaran yang diperolehnya merupakan hasil dari pemahaman, dan penemuannya sendiri. Pembelajaran yang memiliki motivasi tinggi ditunjang dengan pengajar yang yang mampu memfasilitasi motivasi tersebut akan membawa pada keberhasilan sebuah pencapaian target belajar. Menurut Trianto (2010:17) "Pembelajaran merupakan aspek kegiatan manusia yang kompleks, yang tidak sepenuhnya dapat di jelaskan". Pembelajaran secara simpel dapat diartikan sebagai produk interaksi berkelanjutan antara perkembangan dan pengalaman hidup. Pembelajaran dalam makna kompleks adalah usaha sadar dari seorang guru untuk membelajarkan siswanya (mengarahkan interaksi siswa dengan sumber belajar lainnya) dalam rangkaian mencapai tujuan yang di harapkan.

Kegiatan belajar dalam keseluruhan proses pendidikan di sekolah merupakan kegiatan yang paling pokok. Pembelajaran berlangsung sebagai suatu proses saling mempengaruhi antara guru dan siswa. Menurut Gagne (dalam Slameto, 2010:13) memberikan dua definisi belajar, yakni: (1) Belajar adalah suatu proses untuk memperoleh motivasi dalam pengetahuan, keterampilan, kebiasaan, dan tingkah laku; dan (2) Belajar adalah penguasaan pengetahuan atau keterampilan yang di peroleh dari instruksi. Dalam hal ini, kegiatan yang terjadi adalah guru mengajar dan siswa belajar. Dengan kata lain, belajar adalah proses dimana seseorang akan mendapatkan pengetahuan, keterampilan, dan kepribadian sebagai bekalnya untuk masa 
depan. Disinilah peran guru sangat penting untuk menerapkan proses belajar yang mampu mengasah kompetensi siswa, tak hanya secara teori, tetapi juga sikap dan mental siswa. Oleh sebab itu perlu adanya perbaikan pola atau model pembelajaran agar pembelajaran menjadi lebih menarik bagi siswa.

SMA Negeri 4 Singaraja merupakan salah satu sekolah menengah atas yang terdapat di Singaraja. Lingkungan sekolah yang kondusif menyebabkan proses belajar mengajar menjadi optimal dan dapat menciptakan SDM yang berkompeten. Namun dalam kegiatan pembelajaran di kelas menunjukan kurangnya perhatian siswa terhadap pembelajaran yang diberikan oleh guru. Dalam proses pembelajaran di kelas masih dijumpai adanya siswa yang tidak mau bertanya pada guru, meskipun sebenarnya mereka belum mengerti tentang materi yang disampaikan. Ketika guru menanyakan bagian mana yang belum mereka mengerti, seringkali siswa tidak menjawab dan setelah guru memberikan soal latihan maka terlihat bahwa ada beberapa siswa yang belum mengerti dengan materi yang diajarkan. Maka dalam melaksanakan proses belajar mengajar diperlukan model pembelajaran yang sistematis untuk mencapai tujuan belajar yang telah ditentukan.

Metode yang selama ini di terapkan di kelas tersebut adalah Metode Demontrasi. Dimana dari metode ini terlihat bahwa guru yang secara aktif menjelaskan materi di depan kelas, sehingga membuat kurangnya timbal balik murid terhadap pembelajaran. Dengan metode demontrasi murid menjadi kurang aktif dalam mencari dan memahami sebuah materi yang menyebabkan hasil belajar dari murid tersebut sebagian besar tidak dapat memenuhi KKM yang telah di tentukan. Ketidak berhasilan Metode Demontrasi dapat di lihat dari ketuntasan KKM siswa beberapa tahun sebelumnya. Berikut merupakan grafik ketuntasan siswa.

Prayogo dan Ayu Silviana dalam Restu Wijayanto (2014: 28) juga mengemukakan bahwa metode GGE adalah Suatu format diskusi yang memberikan tugas-tugas yang berbeda diberikan kepada kelompok siswa yang berbeda. Metode GGE menuntut siswa untuk berfikir tentang apa yang siswa pelajari, memberi kesempatan berdiskusi atau bersosialisasi dengan teman, bertanya dan berbagi pengetahuan kepada teman lainnya. Metode GGE merupakan pembelajaran yang menerapkan langkah cepat, menyenangkan, mendukung dan menarik hati. Prosedur pembelajaran tipe GGE menurut Silberman (2009: 178) sebagai berikut:

a. Memilih suatu topik mengandung beragam gagasan, peristiwa, posisi, konsep atau pendekatan untuk ditugaskan pada siswa. Topik tersebut haruslah dapat membuat siswa bertukar pandangan atau informasi,

b. Membagi kelas itu ke dalam kelompok sesuai dengan banyak tugas. Kemudian memberi masing-masing kelompok waktu yang cukup untuk mempersiapkan penyajian topik yang ditugaskan pada kelompok tersebut,

c. Ketika tahap persiapan telah diselesaikan. Mintalah pada kelompok untuk memilih siapa sebagai juru bicaranya. Mintalah masing-masing juru bicara untuk mempresentasikan tugas tersebut secara jelas dan ringkas. Kemudian mintalah kepada kelompok lainnya untuk memberikan pertanyaan atau pandangan mereka sendiri terhadap presentasi kelompok penyaji. Apabila ada pertanyaan yang meragukan atau menyulitkan kelompok penyaji untuk menjawab maka anggota kelompok lain diizinkan untuk menjawab,

d. Melanjutkan presentasi berikutnya dari kelompok yang berbeda. Sedemikian sehingga masing-masing kelompok dapat membandingkan informasi dan pandangan yang telah didapatkannya.

Menurut Sudjana (2010: 22), hasil belajar adalah kemampuan yang dimiliki siswa setelah menerima pembelajaran, jika di kaji lebih mendalam, maka hasil belajar dapat tertuang dalam "Taksonomi Bloom", yakni di kelompokkan dalam tiga ranah yaitu kognitif atau kemampuan berfikir, afektif atau sikap, dan psikomotor atau keterampilan. Sehubungan dengan itu, Gagne (dalam Sudjana, 2010: 22) mengembangkan kemampuan hasil belajar menjadi lima macam anara lain: (1) hasil belajar intelektual merupakan hasil belajar yang terpenting dari sistem lingiskolastik; (2) strategi kognitif yaitu mengatur cara belajar dan berfikir seseorang dalam arti seluas - luasnya termasuk kemampuan memecahkan masalah; (3) sikap dan nilai, berhubungan dengan arah intensitas emosional dimiliki seseorang sebagaimanapun disimpulkan dari kecenderungan bertingkah laku terhadap orang dan kejadian; (4) informasi verbal, pengetahuan 
dalam arti informasi dan fakta; (5) keterampilan motorik yaitu kecakapan yang berfungsi untuk lingkungan hidup serta mempresentasikan konsep dan lambang.

\section{Metode}

Jenis penelitian yang dilakukan dalam penelitian ini adalah Penelitian Tindakan Kelas (PTK) atau dalam bahasa Inggris dinamakan Classroom Action Research merupakan suatu penelitian tentang praktik pembelajaran yang dilakukan oleh peneliti itu sendiri (an inquiry on practice from within) Paizaluddin dan Ermalinda (2014). PTK merupakan salah satu upaya peneliti atau praktisi dalam bentuk berbagai kegiatan yang dilakukan untuk memperbaiki, dan atau meningkatkan mutu pembelajaran di kelas.

Pada penelitian ini aspek yang diamati dalam setiap siklusnya adalah hasil belajar siswa yang diukur dengan menggunakan standar kompetensi serta alat ukur yang berskala. Dalam implementasi metode pembelajaran Group to Group Exchange (GGE) dapat melihat perubahan hasil belajar siswa, untuk mengetahui kemajuan belajarnya dengan menggunakan alat pengumpulan data seperti lembar test.

Penelitian ini dilakukan dengan dua siklus. Setiap siklus terdiri dari empat tahapan, yaitu perencanan tindakan, pelaksanaan tindakan, evaluasi, dan refleksi. Siklus I terdiri dari dua kali pertemuan untuk membahas Alat Komunikasi Sederhana yaitu komponen pasif elektronika dan Presentasi kelompok dan satu kali pertemuan tes. Pada Siklus II terdiri dari dua kali pertemuan untuk membahas Alat Komnukikasi Sederhana yaitu Komponen aktid elektronika dan satu kali pertemuan tes. Model penelitian yang dipilih pada penelitian ini adalah model Kemmis \& Taggart, yang memiliki tahapan penting yaitu: 1) Perencanaan tindakan, 2) Pelaksanaan tindakan, 3) Observasi, 4) Evaluasi, dan 5) Refleksi. Menurut Kemmis \& Taggart (dalam Paizaluddin, 2014). Desain penelitian ini dapat dilihat pada Gambar 1 berikut.

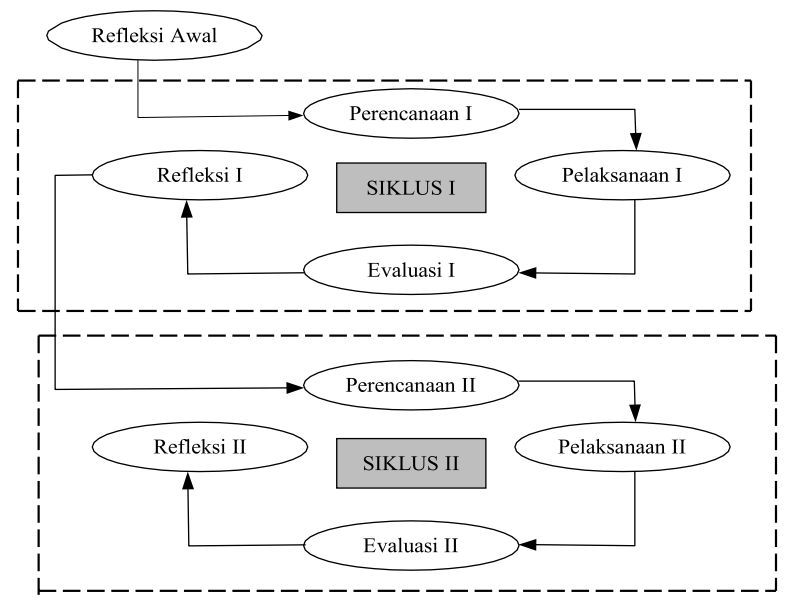

Gambar 1. Rancangan Penelitian diadaptasi dari model penelitian Sumber: Kemmis \& Taggart (dalam Paizaluddin, 2014)

Penelitian ini terdiri dari dua siklus. Siklus I meliputi kegiatan perencanaan, pelaksanaan, observasi/analisis, serta refleksi. Siklus II, sama dengan siklus I, namun pelaksanaannya meninjau dari hasil refleksi pada siklus I. Adapun materi pada tes refleksi awal (pretest) yaitu alat komunikasi sederhana, materi yang diajarkan pada siklus I adalah komponen pasif elektronika, sedangkan untuk siklus II materi yang diberikan adalah komponen aktif elektronika.

Objek penelitian tindakan kelas ini adalah Siswa kelas X MIPA 2 Semester 1 Tahun pelajaran 2016/2017 di SMA Negeri 4 Singaraja yang berjumlah sebanyak 39 siswa dengan 20 laki-laki dan 19 perempuan. Tempat pelaksanaan penelitian di kelas X MIPA 2 SMA Negeri 4 Singaraja. Waktu pelaksanaan penelitian pada tanggal 2 Agustus - 27 September 2016. Instrumen penelitian adalah alat yang digunakan untuk mengukur nilai variabelyang akan diteliti. Adapun instrumen yang akan digunakan dalam penelitian ini adalah penilaian kognitif, afektif, dan psikomotor. Penilaian aspek kognitif dilaksanakan dengan cara memberikan pertanyaan- 
pertanyaan dalam bentuk objektif sesuai dengan materi pembelajaran di kelas.

Tabel 1. Rubrik Penilaian Aspek Kognitif

\begin{tabular}{lll}
\hline Skor & \multicolumn{1}{l}{ Kreteria } \\
\hline & 0 & Tidak menjawab \\
\cline { 2 - 2 } & atau menjawab tetapi salah \\
\hline 1 & Menjawab benar \\
\hline
\end{tabular}

Jumlah soal tes yang digunakan adalah 20 soal untuk siklus I dan 20 soal untuk siklus II. Skor maksimum yang dapat diperoleh adalah 20 dan skor minimum adalah 0 . Skor total siswa diperoleh dengan menjumlahkan skor masing-masing item kemudian skor ini dikonversi skala 100. Penilaian aspek sikap yang dilakukan oleh peneliti didasarkan pada perilaku yang ditunjukkan siswa selama proses pembelajaran dengan menggunakan lembar penilaian afektif atau sikap. Adapun kriteria dari penilaian afektif atau sikap adalah tekun dan tanggung jawab dengan skala 0-4. Penilaian psikomotor dilakukan dengan memberikan tugas berupa makalah dan presentasi kepada siswa untuk dikerjakan yang nantinya akan dinilai pada saat pengumpulan tugas. Adapun kriteria dari penilaian psikomotor adalah ketepatan pengumpulan, materi dan tata tulis dengan skala 0-3. Sebelum instrumen digunakan di dalam penelitian, terlebih dahulu dilakukan pengujian instrumen. Suatu instrumen dikatakan baik apabila memenuhi syarat yaitu valid (Arikunto, 2005:57). Uji coba atau validitas instrumen dilakukan untuk memperoleh gambaran kelayakan dari instrumen yang akan digunakan dalam penelitian.

Validitas isi menunjukkan sejauh mana instrumen yang dibuat sesuai dengan kompetensi dasar (KD) dan indikator. Pengujian validitas isi dilakukan oleh dua ahli/pakar. Sedangkan, instrumen penilaian afektif dan psikomotor hanya divalidasi oleh guru Prakarya dan Kewirausahaan SMA Negeri 4 Singaraja. Teknik pengambilan data hasil belajar Prakarya dan Kewirausahaan dilakukan akhir siklus, baik itu Siklus I dan II. Data yang diperoleh dalam penelitian ini akan dianalisis menggunakan statistik deskriptif. Dalam penelitian ini, untuk menganalisis data menggunakan teknik analisis statistik deskriptif baik deskriptif kuantitatif maupun kualitatif. Menurut Agung (2014:110) analisis deskriptif kuantitatif adalah suatu cara pengolahan data yang dilakukan dengan jalan sistematis dalam bentuk angka-angka dan atau persentase mengenai suatu objek yang diteliti, sedangkan analisis kualitatif adalah suatu cara analisis/pengolahan data dengan jalan menyusun secara sistematis dalam bentuk narasi atau kalimat/kata-kata mengenai suatu objek. Untuk mencari nilai akhir hasil belajar siswa dengan rumus sebagai berikut.

$$
\text { Nilai Akhir }=\frac{\text { NA Kognitif }+ \text { NA Afektif }+ \text { NA Psikomotor }}{3}
$$

Ketuntasan klasikal dihitung dengan menggunakan rumus sebagai berikut:

$$
\text { Ketuntasan klasikal }=\frac{\text { Banyak Siswa Tuntas }(K K M)}{\text { Banyak Siswa yang mengikuti tes }} X 100
$$

Setelah mendapatkan nilai rata-rata hasil belajar, maka hasilnya dikonversikan kedalam pedoman konversi pada Tabel 2 berikut ini (Agung, 2014:118).

Tabel 2 Kriteria tingkat hasil belajar

Hasil belajar siswa dalam pembelajaran secara klasikal diharapkan tercapai $89 \%$. Bilamana indikator keberhasilan tersebut telah terpenuhi atau target tercapai maka siklus penelitian dihentikan. 
Tabel 2. Tingkat Hasil Belajar

\begin{tabular}{ccc}
\hline No & Persentase & Tingkat Hasil Belajar \\
\hline 1 & $90-100$ & Sangat tinggi \\
\hline 2 & $80-89$ & Tinggi \\
\hline 3 & $65-79$ & Sedang \\
\hline 4 & $55-64$ & Rendah \\
\hline 5 & $0-54$ & Sangat Rendah \\
\hline
\end{tabular}

\section{Hasil dan Pembahasan}

Penelitian ini adalah penerapan metode pembelajaran Group to Group Exchange (GGE) untuk meningkatkan hasil belajar siswa pada mata pelajaran Prakarya dan Kewirausahaan di kelas X MIA 2 SMA Negeri 4 Singaraja. Data yang sudah didapat kemudian dianalisis sesuai dengan metode analisis data yang telah dirancang. Hasil tes belajar siswa pada tes awal (pre test) diperoleh jumlah nilai sebesar 1585 banyaknya siswa 39 orang dan nilai rata - rata 40 dan hanya 1 orang yang berhasil mencapai KKM, maka untuk mencapai ketuntasan lebih dari $85 \%$ dapat dilanjutkan ke Siklus I.

Berdasarkan permasalahan yang diperoleh maka pada Siklus I ini diterapkan metode pembelajaran Group to Group Exchange (GGE) pada mata pelajaran Prakarya dan Kewirausahaan. Adapun langkah-langkah yang ditempuh dalam rencana tindakan I adalah: (1) Menentukan materi pelajaran dan membuat rencana pelaksanaan pembelajaran (RPP), (2) Membuat tes siklus I untuk mengukur tingkat kemampuan siswa pada mata pelajaran prakarya dan kewirausahaan, (3) Menyediakan mempresentasikan materi dari masing-masing kelompok. Setelah rencana pembelajaan disusun barulah dilakukan kegiatan pembelajaran.

Pelaksanaan pembelajaran pada Siklus I dilakukan dalam tiga kali pertemuan yang mana pada pertemuan pertama dan kedua difokuskan pada materi dan presentasi kelompok, dan pada pertemuan ketiga dilakukan evaluasi. Pertemuan pertama dilakukan pada tanggal 9 Agustus 2016. Kegiatan ini diawali dengan pemberian salam, kemudian dilakukan absensi siswa dan menjelaskan secara keseluruhan tujuan pembelajaran yang dilaksanakan, waktu yang dipergunakan yaitu kurang lebih 15 menit. Dilanjutkan dengan menjelaskan metodel pembelajaran yang digunakan yaitu Group to Group Exchange (GGE).

Pertemuan kedua dilaksanakan pada tanggal 16 Agustus 2016. Pelaksanaan yang dilakukan pada pertemuan kedua yaitu dengan presentasi dari masing-masing kelompok dengan pokok materi yang telah diberikan yaitu tentang komponen pasif elektronika. Pertemuan ketiga dilaksanakan pada tanggal 23 Agustus 2016. Pada pertemuan ini Siswa diuji pemahaman mengenai materi yang telah diberikan sebelumya dengan memberikan tes pilihan ganda sebanyak 20 butir sebagai tes akhir Siklus I.

Dalam pelaksanaan pembelajaran pada siklus I, diperoleh data tentang hasil belajar komponen pasif elektronika selama proses pembelajaran yang dilakukan sesuai dengan Rencana Pelaksanaan Pembelajaran (RPP) yang telah dibuat pada tahap perencanaan sebelum pembelajaran. Adapun data hasil tes belajar siswa pada Siklus I diperoleh jumlah nilai sebesar 2767 banyaknya siswa adalah 39 orang dengan 22 orang siswa yang tuntas dan 17 orang siswa yang tidak tuntas. Dengan nilai rata-rata kognitif 66,02 , rata-rata nilai afektif 72,12 , dan nilai ratarata psikomotor 75 dengan nilai rata-rata hasil belajarnya adalah 70 serta ketuntasan klasikal mencapai $58 \%$.

Adapun hasil rata-rata dan ketuntasan klasikal siswa pada pre test jika dibandingkan dengan rata-rata pada Siklus I sebesar 40 menjadi 71 yaitu meningkat sebesar 31 . Kemudian ketuntasan klasikal pada pre test sebesar 3\% menjadi 58\% pada Siklus I. Sehingga, peningkatan ketuntasan klasikal dari pre test sampai Siklus I sebesar 55\%. maka untuk meningkatkan hasil belajar siswa perlu diadakan refleksi dalam menentukan perbaikan pembelajaran. Penelitian ini dilanjutkan ke Siklus II karena belum mencapai target yang diharapkan yaitu $85 \%$.

Beberapa kendala atau hambatan hasil pengamatan peneliti selama melakukan tindakan 
pada Siklus I:

1. Siswa belum mampu secara maksimal mengikuti pembelajaran dengan metode pembelajaran Group to Group Exchange (GGE), dengan materi komponen pasif elektronika dimana siswa dalam kelompok kurang aktif dalam penyusunan materi dan diskusi tentang materi yang di berikan ke masing - masing kelompok. Selain itu dalam presentasi beberapa siswa kurang memperhatikan temannya yang sedang presentasi menyampaikan materi di depan kelas.

2. Pada saat pengambilan data masih bnyak siswa yang belum mempersiapkan diri secara maksimal, seperti tidak belajar atau membaca buku sebelum diadakannya pre test. Hal ini menyebabkan siswa dalam menghadapi test mendapatkan nilai di bawah standar yang di harapkan, sehingga ketuntasan belajarnya masih ada di bawah standar kriteria keberhasilan. berikut.

Adapun solusi untuk perencanaan di Siklus II yaitu dengan melakukan tindakan sebagai

1. Membimbing siswa dalam proses diskusi kelompok dalam hal pembahasan materi yang akan di presentasikan di depan kelas agar setiap anggota dalam kelompok dapat menguasai dan mengertimateri secara menyeluruh, sehingga metode pembelajaran Group to Group Exchange (GGE) dapat secara maksimal di lakukan.

2. Memberikan arahan dan bimbingan terhadap siswa saat proses presentasi dan sesi tanya jawab usai presentasi terkait materi yang di bahas agar siswa menjadi terarah baik dalam bertanya dan menjawab pertanyaan yang sedang di bahas.

Berdasarkan data yang telah dipaparkan di atas masih terdapat siswa yang belum mencapai ketuntasan belajar secara klasikal sehingga proses pembelajaran dilanjutkan ke Siklus II. Hasil belajar siswa pada Siklus I ini dijadikan sebagai acuan dalam pemberian tindakan dan menyusun skenario pembelajaran dengan menggunakan metode pembelajaran Group to Group Exchange (GGE) pada Siklus II untuk meningkatkan hasil belajar siswa. Pada pelaksanaan Siklus II dilaksanakan tiga kali pertemuan. Satu kali pertemuan untuk kegiatan pembelajaran, satu kali pertemuan untuk kerja praktek dan pertemuan ke tiga untuk tes akhir Siklus II.

Pertemuan pertama dilakukan pada tanggal 23 Agustus 2016. Kegiatan ini diawalidengan pemberian salam, kemudian dilakukan absensi siswa dan menjelaskan secara keseluruhan tujuan pembelajaran yang dilaksanakan, waktu yang dipergunakan yaitu kurang lebih 15 menit. Selanjutnya dilanjutkan dengan menjelaskan metode pembelajaran yang digunakan yaitu Group to Group Exchange (GGE) dan memberikan komponen aktif elektronika. Diakhir kegiatan pembelajaran, guru mengarahkan siswa untuk merangkum materi pelajaran, kemudian guru memberikan informasi pembelajaran selanjutnya yaitu pembagian sub materi yang berbeda kepada masing-masing kelompok untuk di presentasikan pada pertemuan berikutnya dan kemudian ditutup dengan doa.

Pertemuan kedua dilaksanakan pada tanggal 30 Agustus 2016. Pada pertemuan ini siswa melakukan presentasi kelompok dan tanya jawab terkait materi yaitu komponen aktif elektronika. Pertemuan ke tiga dilaksanakan pada tanggal 20 September 2016. Pada pertemuan ini siswa diuji pemahaman mengenai materi yang telah diberikan sebelumya dengan memberikan tes pilihan ganda sebanyak 20 butir sebagai tes akhir Siklus II.

Dalam pelaksanaan pembelajaran pada Siklus I sebelumnya, ada 5 siswa yang masih belum mencapai Kriteria Ketuntasan Minimal (KKM) yang ditetapkan sekolah sebesar 70. Maka pada Siklus II ini diharapkan agar hasil belajar meningkat, dan 89\% siswa berhasil mencapai KKM. Pada akhir Siklus II diadakan tes evaluasi untuk mengetahui hasil dari pembelajaran Siklus II. Bentuk tes yang diberikan adalah tes objektif dengan jumlah soal 20 butir.

Adapun data hasil tes belajar siswa pada Siklus II diperoleh jumlah nilai sebesar 3053 banyaknya siswa adalah 39 orang dengan 30 orang siswa yang tuntas dan 5 orang siswa yang tidak tuntas. Dengan nilai rata-rata kognitif 80,51 , rata-rata nilai afektif 74,35 , dan nilai rata-rata psikomotor 79,97 dengan nilai rata-rata hasil belajarnya adalah 78,27 serta ketuntasan klasikal mencapai $89 \%$.

Adapun hasil rata-rata dan ketuntasan klasikal siswa pada Siklus I jika dibandingkan dengan rata-rata pada Siklus II sebesar 71 menjadi 78 yaitu meningkat sebesar 7 . Kemudian ketuntasan klasikal pada Siklus I sebesar 58\% menjadi $89 \%$ pada Siklus II. Sehingga, 
peningkatan ketuntasan klasikal dari Siklus I sampai Siklus II sebesar 31\%. Oleh karena hasil belajar pada Siklus II sudah mencapai atau melebihi target yang diharapkan, maka penelitian ini dihentikan di Siklus II. Untuk memperjelas peningkatan hasil dari pelaksanaan pre test, Siklus I sampai Siklus II akan ditampilkan pada Grafik 1 sebagai berikut.

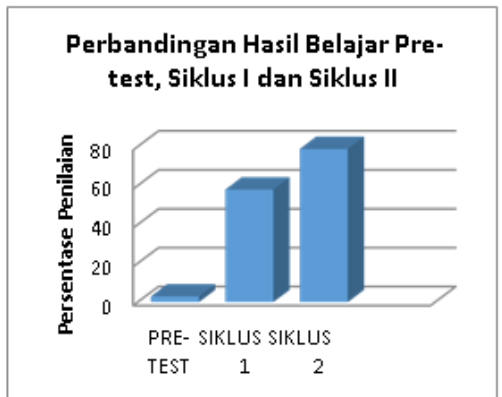

Grafik 1. Perbandingan Hasil Belajar Pre Test, Siklus I dan Siklus II

Berdasarkan penerapan rancangan pada Siklus II yang merupakan perbaikan dari tindakan pada Siklus I, memberikan hasil berupa peningkatan hasil belajar yang cukup signifikan. Dengan demikian, dapat dinyatakan bahwa penerapan metodel pembelajaran Group tp Group Exchange (GGE) di kelas X MIPA 2 SMA Negeri 4 Singaraja dapat meningkatkan hasil belajar siswa.

\section{SIMPULAN}

Dari hasil refleksi yang telah disampaikan di pembahasan dan dengan melihat semua data yang telah dipaparkan, dapat disampaikan bahwa pencapaian tujuan penelitian di atas dapat dibuktikan dengan argumentasi sebagai berikut. Dari data awal ada 38 siswa mendapat nilai di bawah KKM dan pada Siklus I menurun menjadi 17 siswa dan Siklus II hanya 5 siswa mendapat nilai di bawah KKM. Nilai rata-rata kognitif pada Siklus I sebesar 66,02 naik menjadi 74,28 pada Siklus II. Nilai rata-rata afektif pada Siklus I sebesar 72,68 naik menjadi 80,51 pada Siklus II. Nilai rata-rata psikomotor pada Siklus I sebesar 75 naik menjadi 79,97 pada Siklus II. Nilai rata-rata awal 40 naik menjadi 71 pada Siklus I dan pada Siklus II naik menjadi 78,27. Ketuntasan belajar klasikal juga meningkat dari $57.14 \%$ pada siklus I menjadi sebesar $78 \%$ pada siklus II. Terjadi peningkatan dilihat dari hasil belajar pada siklus I sebesar 71 dan pada siklus II sebesar 78,27 sehingga peningkatanya sebesar 7,27.

\section{DAFTAR PUSTAKA}

Agung, A. A. Gede. 2014. Buku Ajar Metodologi Penelitian Pendidikan (Edisi 2). Singaraja: Aditya Media Publising.

Arikunto, Suharsimi dkk. 2007. Penelitian Tindakan Kelas. Jakarta: Bumi Aksara.

Arikunto, Suharsimi. 2013. Prosedur Penelitian Suatu Pendekatan Praktik.

Arikunto. 2005. Dasar-Dasar Evaluasi Pendidikan. Jakarta: PT Bumi Aksara.

Nana Sudjana 2010. Dasar-dasar Proses Belajar, Sinar Baru Bandung Nana Sudjana 2010. Dasar-dasar Proses Belajar, Sinar Baru Bandung.

Paizaluddin, dan Ermalinda. 2014. Penelitian Tindakan Kelas (Classroom Action Research) Panduan Teoritis dan Praktis. Bandung: Alfabeta.

Purwanto, Nanang 2014. Pengantar Pendidikan. Yogyakarta: Graha ilmu.

Silberman Melvin L. (2009). Active Learning: 101 Cara Belajar Siswa Aktif (Alih bahasa: Raisul Muttaqien). rev.ed. Bandung: Nusamedia. 
Slameto. 2010. Belajar Dan Faktor-faktor Yang Mempengaruhinya. Jakarta: Rineka Cipta.

Trianto. 2010. Model Pembelajaran Terpadu. Jakarta: Bumi Aksara 